\title{
SPATIAL DIFFERENTIATION OF THE REGIONS OF UKRAINE CONCERNING THE KNOWLEDGE ECONOMY
}

\author{
lesia DMYTRYSHYN ${ }^{1}$, Viktoriia BUSHYNSKA² \\ Vasyl Stefanyk Precarpathian National University, Ukraine
}

\begin{abstract}
The purpose of the research is a set of theoretical and methodological, methodical and applied provisions concerning the analysis of economic development built on knowledge (KE) in the regions of Ukraine and also the determination of their integral estimation of KE development level. Methodology. The research methodology is based on a systematic approach, within which analysed KAM methodology (Knowledge Assessment Methodology) developed by theWorld Bank, identified key groups of indicators, such as the general condition of regional economies, economic stimulus and the characteristics of the institutional system, innovation, R\&D sector and informational infrastructure. Considered the key factors that determine the position of knowledge in the regional development, namely: the business community, the scientific environment and the system of self-government, which forms regional policy in the light of specific conditions of areas. The possibility of this methodology's application in the regional aspect is determined. For the research are chosen all regions of Ukraine. Exceptions are temporarily occupied territory. Accordingly, histograms of each of the key indicators' groups are built that help to determine the level of development of a particular region. Results. Established that the symbiosis of innovative potential with the unique economic mechanisms is the catalysts that enhance the development of the regional knowledge economy. This analysis helps to see social and economic differences between the regions of Ukraine. Determined that the characteristic feature is an inadequate level of funding of science, which causes the slowdown of innovation activity in the regions because of links imbalance between industry and research industry sector. In most cases, the regions occupied similar positions in different groups of indicators. This allows us to conclude that the development of the knowledge economy components in the region is balanced. Noteworthy the fact that during analysing each of the indicators groups, the lion's share of regions was located around the median value, which points to the similarity of the condition of knowledge development in the economy of the regions. Highlighted powerful, competitive and potentially most perspective regions in terms of KE development in 2015. The practical implication of the results is findings and proposals for the formation of a regional knowledge economy development strategy. Found that the program support of the knowledge economy development should aim at the accelerated and harmonious growth of all triad elements "education - science - manufacturing" and their resulting components.
\end{abstract}

Key words: economy of knowledge, innovations, knowledge assessment methodology, Ukraine regions, spatial aspect, system analysis.

JEL Classification: 125, 128, 018, P40, R11

\section{Introduction}

At the current stage within the legal and political system in Ukraine, the regions are the basic units of territorial division, which have local self-administration. In an economic sense, the regions are a subsystem of the territorial economy of the country, and within their borders, the institutional processes occur. Since the regions do not have sovereignty and associated legal regulations, their nature is determined by the internal structure (e.g. number of economic subjects, the production efficiency but, at the same time, employment and unemployment and the business environment), external structure (i.e. commodity and financial flows) and total assets (size of gross regional product - GRP).

Today the ideas of classical theories have receded into the background, and the region is only considered as a place of localization of certain types of activities. Currently, the region can be interpreted as a place where innovations are generated, and where there are processes of their absorption and diffusion. That is, the region should be considered as the fundamental

\footnotetext{
Corresponding author:

${ }^{1}$ Department of Economic Cybernetics, Vasyl Stefanyk Precarpathian National University.

E-mail: dmytryshyn_1@hotmail.com

${ }^{2}$ Department of Economic Cybernetics, Vasyl Stefanyk Precarpathian National University.

E-mail: tori55@i.ua
} 
organization level of the economy, and as a sphere for the creation of knowledge and innovations and technical and technological skills (Christopherson, 2008; Pike, Rodríguez-Pose, \& Tomaney, 2016). Of course, each region has its own features inherent only in it. In different areas, there are different mechanisms of development and application of innovations, especially the mechanisms of education and qualification training, as well as the ability to cooperate and create links in the form of entire network systems.

\section{Economy of knowledge - a feature of the regional competitiveness}

Therefore, it can be argued that the innovative ability is determined by the regional potential as well as due to the ability of any spatial structure to generate and distribute innovations. The innovative sphere is developed in quite different way in those planes where there is a strong and dominant centre of the metropolis that is in planes with multi-function structure. On the territory, where separate subjects of international importance operate, the development of innovative processes is different than in those areas where the sector of small and medium enterprises is well developed. The coexistence of exceptional innovative potential together with unique mechanisms that are unique to the certain region creates the essence of the regional economy based on knowledge (Cooke \& Memedovic, 2003; Cooke \& Schienstock, 2000). On the base of these considerations, we focus on those catalysts, which enhance the regional economic development based on knowledge.

The first engine of the development of the regional economy based on knowledge is the business environment. Enterprises should produce knowledge themselves by obtaining and using knowledge with the aim of achieving lasting competitive advantages that increase their value in the marketplace. The second initiator of the creation of the economy based on knowledge is the scientific environment. These subjects mainly generate theoretical knowledge and their practical application will lead to significant dissemination of knowledge for the requirements of socio-economic growth. The last element in this system - the system of self-government, which forms the regional policy through the prism of a deep knowing of the special conditions of the territory, which it covers. State authorities should monitor the development of the economy based on knowledge as the most strategic process.

The knowledge-based economy is closely associated with the community of people who learn. However, education cannot be seen only as a direct transfer of information. Education is a joint process of individual interconnected elements that get an education, which, in its turn, leads to the so-called social capital. Effective improvement of professional qualifications is connected with several postulates:

1. Continuous professional training of the employee during his entire professional career is necessary (it concerns, first of all, institutions outside the university).

2. The employee must be continuously adapted to changes in the location and nature of a job.

3. The training should also include skills training to produce own and create new knowledge.

It is considered that the increase in the efficiency of education, resulting in the social capital formation is the main factor of the regional development, and the ability of regions to adapt to the requirements of the economy based on knowledge. Education and skills become a strong attribute in a particular market. Investments in human resources are required to increase public capacity since the employees with the competence, experience, motivation and engagement are the creators of the intellectual capital of the enterprise. It is worth saying that the importance of human capital does not change in direct proportion to the change of the number of people. It is better to consider the level of this capital in the qualitative perception than in a quantitative one because it does not obey all the rules of the market.

One should pay an attention to the fact that culture in the broadest sense of this word plays an important role in the economy based on knowledge. It deals with social elites and development of cultural centres, as well as entrepreneurship and work culture. Another manifestation of the regional development is the perception of the future. These questions can be directly linked to migration, consumption and investment decisions. That is why poorer regions have the greatest problem with the shortage of people with knowledge. Even if there are highly skilled workers in this area, there is the process of migration in conditions of the lack of jobs for them. Other regions will use income generated by these workers, or, what is worse, such persons will be employed in other spheres and will not realize their inner potential.

All these aspects affect the formation of the competitiveness of the region, which creates favourable conditions for local business, and it is more competitive due to the search for investment capital, and this fact facilitates the inflow of foreign investments.

\section{Empirical analysis}

To determine the state of development of the regional economy based on knowledge in Ukraine, the input data set will contain diagnostic functions, taking into account all aspects of such an economy. It consists of 5 key groups of indexes formed in a similar way to the methodology (Chen \& Dahlman, 2005):

1) the characteristic indexes of the general state of the economy;

2) the indexes of economic stimulus and the characteristics of the institutional structure; 
3) the indexes of innovation activities in the region;

4) the indexes of R\&D sector;

5) the indexes of the development level of information infrastructure.

These indexes were analysed concerning regions of Ukraine in 2015. The extrapolation method was used to eliminate gaps in the dataset. This sample was divided into stimulants and destimulants, which were presented with the opposite sign. They include the following indexes: proportion of population with average person equivalent total income per month below the subsistence level (\%), provision of population with medical hospital beds, number of crimes (cases per thousand persons), unemployment rate (\%) unemployment rate of women (\%) unemployment rate of men (\%). The results of the conversions were normalized.

Selected data ("State Statistics Service of Ukraine," 2015) array of diagnostic indicators for the study is so large that it is impossible to represent it for each region in each year. Therefore, it was decided to represent each group of indexes separately for the last study period (Fig. 1-5). Each figure shows the deviation of the development level of the 22 regions (excluding the temporarily occupied territories) in the context of a specific group of classification features.

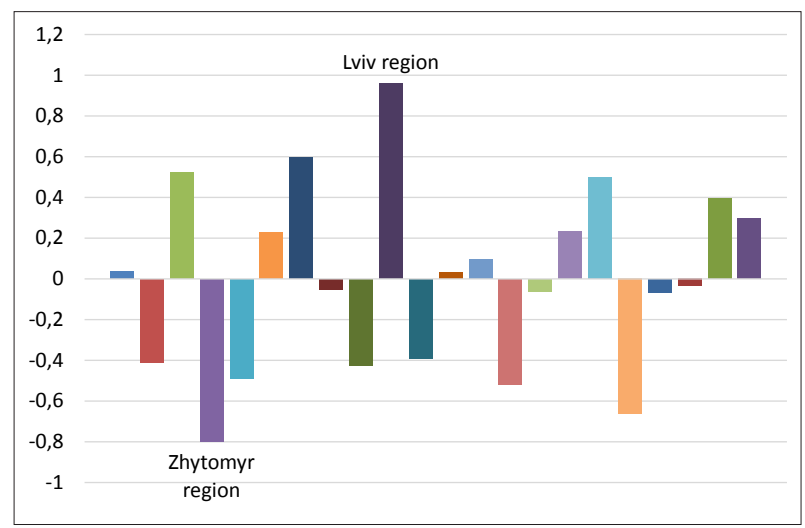

Fig. 1. The level of characteristic indexes of the general state of the economy of Ukrainian regions in 2015

Most regions during the diagnostics of the level of economic development of regions (Fig. 1) showed a significant deviation from the medium level. The highest level is presented in the Lviv region, due to the significant growth of the gross regional product, the long life expectancy of the population among women and men, as well as the growth in the number of workplaces. The lowest level of economic development of the region is presented in the Zhytomyr region, due to a relatively weak level of industrial development, which is reflected in the GRP. In its turn, a high level of morbidity has also played its role.

Among the indexes of economic stimulus and institutional structure (Fig. 2) the Dnipro region has the highest level, but Kharkiv region has also rather high level. These results were achieved thanks to high rates of capital formation, which was caused by a large number of loans to small and medium businesses. Also, it is worth saying that these regions are safe enough according to the crime statistics. Kirovohrad and Zaporizhzhia regions are the antagonists respectively to these regions.

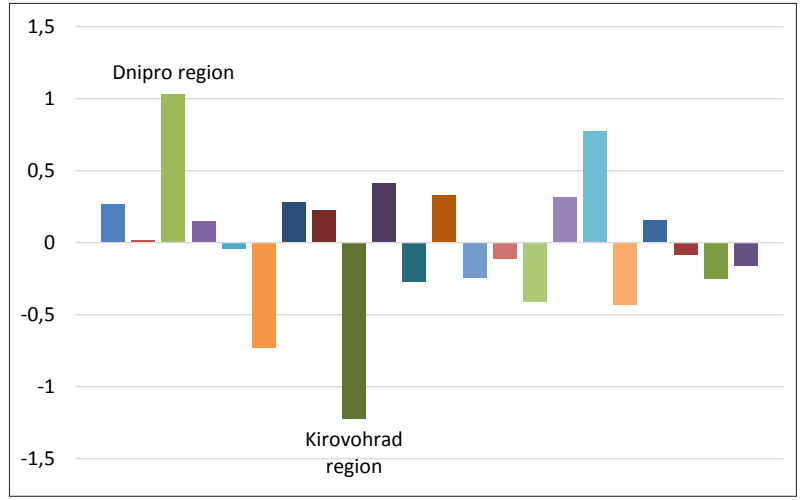

Fig. 2. The level of economic stimulus indexes and characteristics of institutional structure of the regions of Ukraine in 2015

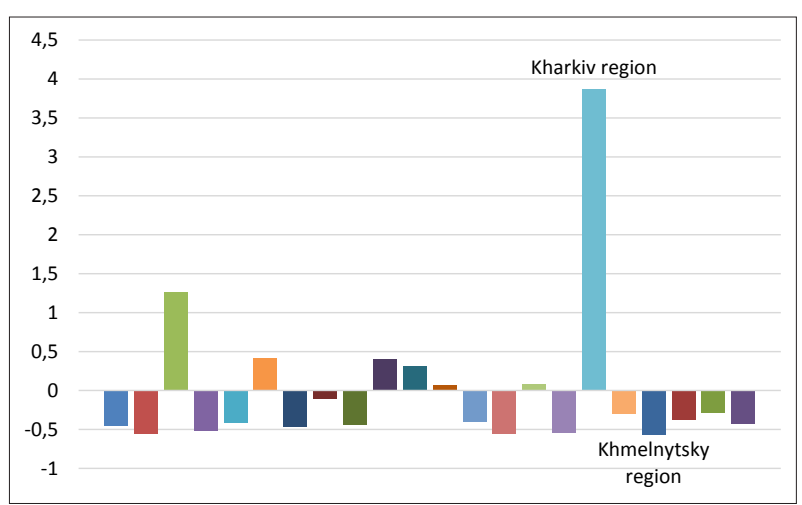

Fig. 3. The level of characteristic indexes of innovative activity of the Ukrainian regions in 2015

The level of innovation activity of the regions (Fig. 3) is directly linked to a large number of factors that influence it, for example, the number of students of educational institutions, the number of studies conducted for the R\&D sector, as well as the volume of their subsidy amounts. Kharkiv and Dnipro regions are the leaders in terms of the innovative development of the regions of Ukraine. This fact is directly related to the population size and concentration of production capacities, which in its turn determined this course of events.

As to the level of indexes of R\&D sector (Fig. 4), they can be divided into two groups:

1) education (number of students of educational institutions, researches, conducted for the R\&D sector, as well as their subsidy amounts);

2) labour force (unemployment rate, employment rate, level of economic activity of the population of the region).

Kharkiv and Dnipro regions managed again to achieve the best results. This is because the $R \& D$ 
sector is the basis for innovation activities. Therefore, without a doubt, the result was expected. But a very low level of development of scientific researches in Ternopil region was surprising. The relatively low level of population employment in the industrial sector and high unemployment level were the root causes of this phenomenon.

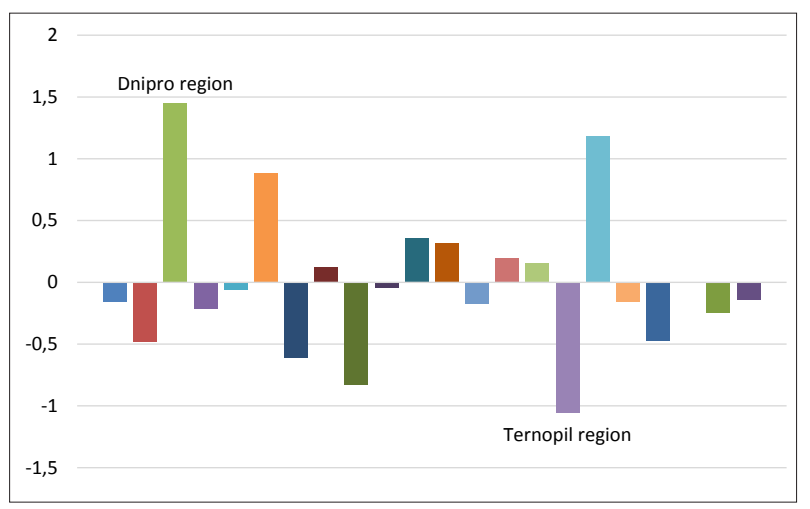

Fig. 4. The level of characteristic indexes of the R\&D sector of the Ukrainian regions in 2015

Odesa region stands out with its development level of information infrastructure (Fig. 5), which is reflected in large indexes of the presence of the telephone lines, subscribers of cable television and the Internet.

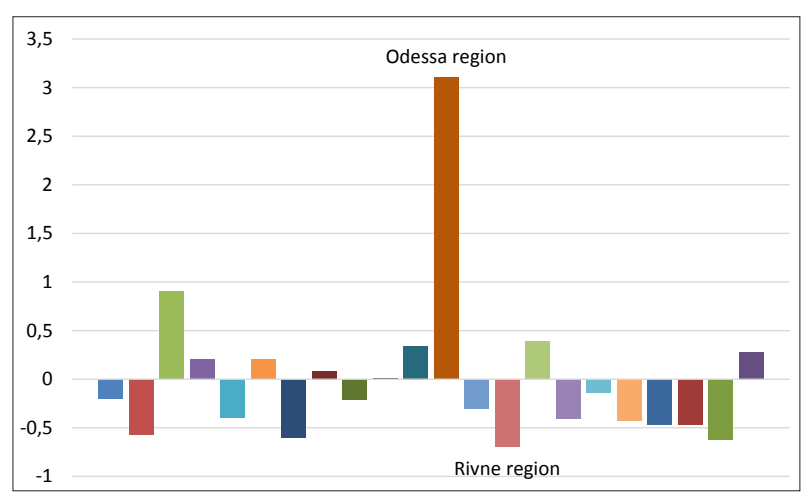

Fig. 5. The level of development indexes of informational infrastructure of the Ukrainian regions in 2015

\section{Conclusions}

Application of spatial statistics and multivariate comparative analysis made it possible to assess the state of the regional economy based on knowledge. Noteworthy is the fact that the analysis allows seeing social and economic differences between the regions of Ukraine and could be the basis for creating and maintaining a common regional policy. The factors that served as the basis for the research are formed in accordance with the methodology, developed by the World Bank. In most cases, the regions occupied similar positions in different groups.

\section{References:}

Chen, D. H., \& Dahlman, C. J. (2005). The knowledge economy, the KAM methodology and World Bank operations. Retrieved from: http://documents.worldbank.org/curated/en/695211468153873436/Theknowledge-economy-the-KAM-methodology-and-World-Bank-operations

Christopherson, S. (2008). Local and Regional Development. By Andy Pike, Andrés Rodríguez-Pose and John Tomaney. Economic Geography, 84(2), 241-242.

Cooke, P., \& Memedovic, O. (2003) Strategies for regional innovation systems: learning transfer and applications (pp. 15-19): United Nations Industrial Development Organization Vienna.

Cooke, P., \& Schienstock, G. (2000). Structural competitiveness and learning regions. Enterprise and Innovation Management Studies, 1(3), 265-280.

Pike, A., Rodríguez-Pose, A., \& Tomaney, J. (2016). Concepts and theories of local and regional development Local and regional development (pp. 61-70): Routledge.

State statistics service of Ukraine. (2015). Retrieved from: http://ukrstat.gov.ua

\section{Леся ДМИТРИШИН, Виктория БУШИНСКАЯ \\ ПРОСТРАНСТВЕННАЯ ДИФФЕРЕНЦИАЦИЯ ЭКОНОМИКИ ЗНАНИЙ}

Аннотация. Предметом исследования является комплекс теоретико-методологических, методических и прикладных положений относительно анализа развития экономики построенной на знаниях (ЭЗ) в регионах Украины, а также определение их интегральной оценки уровня развития ЭЗ. Методика. В основу методологии исследования положен системный подход, в пределах которого проанализирована методология КАМ (Knowledge Assessment Methodology) Мирового Банка, идентифицировано ключевые группы показателей, такие, как: общего состояния экономики регионов, экономических стимулов и характеристики институционного порядка, инновационной деятельности, сектора R\&D и информационной инфраструктуры. Рассмотрены основные факторы, которые определяют место знаний в развитии региона, а именно: бизнес среда, научная среда, а также система самоуправления, которая формирует региональную политику сквозь призму особых условий развития территорий. Определены возможности адаптации данной методологии в региональном разрезе. Для проведения исследования были избраны все регионы Украины. Исключениями 
служили временно оккупированные территории, а также места проведения боевых действий. Согласно этому было построено гистограммы каждой из ключевых групп показателей, с помощью которых можно определить уровень развития конкретного региона. Результаты. Установлено, что симбиоз инновационного потенциала с уникальными экономическими механизмами есть теми катализаторами, которые усиливают развитие региональной экономики знаний. Благодаря данному анализу удалось увидеть социальные и экономические отличия между регионами Украины. Определено, что характерной особенностью является недостаточный уровень финансирования науки, который в свою очередь предопределяет замедление инновационной деятельности в регионах через дисбаланс связей между промышленностью и отраслевым научным сектором. Доказано, что постепенное снижение инновационной деятельности регионов приведет к потери инновационного потенциала государства в целом, которое ослабляет позиции Украины в международном рейтинге и делает невозможным привлечение научных учреждений и инновационных предприятий к реализации общих проектов. В большинстве случаев регионы занимали похожие позиции в разных группах показателей. Это позволяет сделать вывод о равномерном развитии компонентов экономики знаний в регионах. Также следует заметить, что во время анализа каждой из групп показателей львиная доля областей располагалась вокруг медианного уровня, который указывает на сходство состояния развития знаний в экономике регионов. Выделено мощные, потенциально конкурентоспособные и наиболее перспективные с точки зрения развития ЭЗ регионы-лидеры по состоянию на 2015 год. Практическое значение. Практическое значение полученных результатов заключается в том, что можно сделать выводы и предложения относительно формирования региональной стратегии развития экономики, построенной на знаниях. Выявлено, что программная поддержка развития экономики знаний должна быть направлена на ускоренное и гармоническое развитие всех элементов триады «образование - наука - производство» и их результирующих компонентов. 